\title{
PENGARUH PROFITABILITAS TERHADAP NILAI PERUSAHAAN PADA SEKTOR ANEKA INDUSTRI YANG TERCATAT DI BURSA EFEK INDONESIA
}

\author{
Oleh: \\ Sepbeariska Manurung \\ S1 Akuntansi \\ Darwin Lie, Mahaitin Sinaga, Jubi
}

Abstraksi

Tujuan dari penelitian ini adalah untuk mengetahui gambaran profitabilitas yang diukur dengan return on equity (ROE), mengetahui gambaran nilai perusahaan dengan market to book ratio (MBR) dan mengetahui besar pengaruh profitabilitas terhadap nilai perusahaan sektor aneka industri yang tercatat di Bursa Efek Indonesia. Metode yang digunakan dalam penelitian ini adalah metode analisis deskriptif. Penelitian ini dilakukan berdasarkan data sekunder dari laporan keuangan perusahaan yang diperoleh dari idx statistik.

Penelitian ini menggunakan statistik deskriptif, uji asumsi klasik dan uji hipotesis dengan menggunakan bantuan SPPS 17.0. Sampel yang digunakan adalah perusahaan sektor aneka industri yang tercatat di Bursa Efek Indonesia tahun 2009 sampai dengan tahun 2012. Profitabilitas merupakan variabel independen dan nilai perusahaan merupakan variabel dependennya. Hasil penelitian ini menyebutkan bahwa rata-rata tingkat profitabilitas yang diproksikan oleh return on equity yang dihasilkan oleh perusahaan sektor aneka industri yang tercatat di Bursa Efek Indonesia adalah sebesar 13,47\%, sementara rata-rata nilai perusahaan yang diproksikan oleh market to book ratio pada perusahaan sektor aneka industri yang tercatat di Bursa Efek Indonesia adalah sebesar 1,002040. Hal ini berarti profitabilitas berpengaruh positif dan signifikan terhadap nilai perusahaan.

Kata kunci: Profitabilitas dan Nilai Perusahaan

Abstract

The purpose of this research is to know the description of profitability as measured by return on equity $(R O E)$, know the firm value with the market to book ratio $(M B R)$ and knowing the great influence of profitability towards the firm value sectors of industrial company listed on the Indonesia Stock Exchange. The methods used in this research is descriptive analysis method. This research was conducted based on secondary data from the financial reports of companies that obtained from idx statistics.

This research uses descriptive statistics, classic assumption test and test hypotheses using SPPS 17.0. The sample used is various industry sectors companies were listed on the Indonesia Stock Exchange in 2009 up to the year 2012. Profitability is the independent variable and the variable dependen is firm value. Results of these research mention that the average level of profitability which proxy is return on equity generated by sectors of industrial company were listed on the Indonesia Stock Exchange was 13,47\%, while the average of firm value which proxy is market to book ratio on sectors of industrial company were listed on the Indonesia Stock Exchange was 1,002040. This mean that profitability has the positive and significant influence towards the firm value sectors of industrial company.

Keywords: Profitability and Firm Value

\section{A. PENDAHULUAN}

\section{Latar Belakang Masalah}

Pasar modal adalah tempat pertemuan yang memfasilitasi interaksi antara pembeli dan penjual untuk menentukan harga saham atau surat berharga. Pasar modal juga memberi kesempatan kepada para pemodal untuk menentukan hasil yang diharapkan dan memberikan kesempatan kepada investor untuk menjual kembali saham yang dimilikinya serta memberikan kesempatan kepada masyarakat untuk berpartisipasi dalam perkembangan suatu perekonomian negara.

Nilai perusahaan yang semakin meningkat mengindikasikan kemakmuran pemegang saham juga semakin meningkat. Teori-teori di bidang keuangan perusahaan menurut Atmaja (2008) memiliki satu fokus yaitu bagaimana memaksimumkan kemakmuran pemegang saham atau pemilik perusahaan (wealth of the shareholders). Dikatakan makmur apabila pemegang saham memperoleh keuntungan dari setiap lembar saham atas investasi yang ditanamkannya. Keuntungan yang diperoleh berasal dari meningkatnya harga saham di pasar modal. Meningkatnya harga saham perusahaan berarti nilai perusahaan itu sendiri pun akan meningkat.

Berdasarkan latar belakang masalah di atas, dalam hal ini penulis ingin mengetahui mengenai pengaruh profitabilitas terhadap nilai perusahaan. Untuk itu penulis melakukan penelitian mengenai 
pengaruh profitabilitas terhadap nilai perusahaan yang saham-sahamnya diperjual-belikan di Bursa Efek Indonesia. Alasan melakukan penelitian di Bursa Efek Indonesia dikarenakan penulis yakin laporan keuangan yang disajikan oleh perusahaanperusahaan di atas akurat dan dapat dipercaya serta telah diaudit oleh kantor akuntan yang independen. Mengingat ada banyak perusahaan yang tercatat di Bursa Efek Indonesia dengan jenis operasi yang bervariasi, maka penulis membatasi penelitian hanya kepada perusahaan yang relatif sejenis yaitu pada sektor aneka industri saja. Oleh karenanya judul yang diambil oleh penulis dalam penelitian ini adalah "Pengaruh Profitabilitas Terhadap Nilai Perusahaan pada Sektor Aneka Industri yang Tercatat di Bursa Efek Indonesia”.

\section{Rumusan Masalah}

Berdasarkan permasalahan di atas, rumusan masalah dalam penulisan ini adalah sebagai berikut :

a. Bagaimana gambaran profitabilitas dan nilai perusahaan pada sektor aneka industri yang tercatat di Bursa Efek Indonesia?

b. Seberapa besar pengaruh profitabilitas terhadap nilai perusahaan pada sektor aneka industri yang tercatat di Bursa Efek Indonesia?

\section{Tujuan Penelitian}

Berdasarkan rumusan masalah di atas, maka dapat di ketahui bahwa tujuan penelitian adalah:

a. Untuk mengetahui gambaran profitabilitas dan nilai perusahaan pada sektor aneka industri yang tercatat di Bursa Efek Indonesia

b. Untuk mengetahui seberapa besar pengaruh profitabilitas terhadap nilai perusahaan pada Sektor Aneka Industri yang tercatat di Bursa Efek Indonesia.

\section{Metode Penelitian}

Desain penelitian merupakan suatu cara yang sistematis dan objektif dengan maksud untuk memperoleh data atau mengumpulkan keterangan untuk diteliti. Adapun desain penelitian yang digunakan dalam penelitian ini adalah penelitian kepustakaan (library research).

Objek penelitian ini adalah perusahaan Sektor Aneka Industri yang tercatat di bursa efek Indonesia dari tahun 2008-2012. Menurut data, terdapat 40 perusahaan Sektor Aneka Industri yang tercatat di Bursa Efek Indonesia. Sampel yang digunakan adalah memenuhi kriteria rasio-rasio keuangan yang digunakan dalam variabel penelitian. Dari hasil purposive sampling, maka sampel perusahaan yang dipakai dalam penelitian ini adalah sebanyak 18 perusahaan.

Metode analisis yang digunakan untuk menguji hipotesis dalam penelitian ini adalah analisis regresi linier sederhana dan oleh karenanya uji asumsi klasik harus terlebih dahulu dilakukan. Uji asumsi klasik yang dilakukan antara lain uji normalitas, uji heteroskedastisitas dan uji autokorelasi. Teknik analisis data dalam penelitian ini menggunakan alat bantu software SPSS (Statistical Product and Service Solutions).

\section{B. TINJAUAN PUSTAKA}

\section{Rasio Keuangan}

Dalam praktiknya, terdapat beberapa macam jenis rasio keuangan yang dapat digunakan untuk mengukur kinerja suatu perusahaan. Masing-masing jenis rasio digunakan akan memberikan arti tertentu tentang posisi yang diinginkan. Menurut Brigham \& Houston (2012:133), ada 5 jenis rasio keuangan yaitu:

a. Liquidity ratio, yaitu rasio yang menunjukkan hubungan antara kas dan asset lancar perusahaan lainnya dengan kewajiban lancarnya.

b. Asset Management Ratios, yaitu rasio yang mengukur seberapa efektif sebuah perusahaan mengatur asetnya.

c. Financial Leverage, yaitu rasio yang menggambarkan penggunaan pendanaan utang.

d. Profitability Ratios, yaitu sekelompok rasio yang menunjukkan kombinasi dari pengaruh likuiditas, manajemen aset, dan utang pada hasil operasi.

e. Market Value Ratios, yaitu sekumpulan rasio yang menghubungkan harga saham perusahaan dengan laba, arus kas, dan nilai buku per sahamnya.

\section{Profitabilitas}

Menurut Atmaja (2008), rasio profitabilitas adalah rasio yang mengukur kemampuan perusahaan menghasilkan laba. Menurut Horne \& Wachowics (2012:180), ada dua tipe rasio profitabilitas, yaitu yang menunjukkan profitabilitas sehubungan dalam kaitannya dengan penjualan, dan yang menunjukkan profitabilitas dalam kaitannya dengan investasi.

\section{Nilai Perusahaan}

Menurut Brigham \& Houston (2010:15), rasio nilai pasar (market value ratios) berhubungan dengan harga saham perusahaan terhadap laba, arus kas dan nilai buku per sahamnya. Rasio ini memberikan indikasi bagi manajemen tentang bagaimana pandangan investor terhadap resiko dan prospek perusahaan di masa depan. Jika rasio likuiditas, manajamen aset, manajemen utang, dan profitabilitas semuanya terlihat baik - dan jika kondisi ini berjalan terus menerus secara stabil-maka rasio nilai pasar juga akan tinggi, harga saham kemungkinan tinggi sesuai dengan yang diperkirakan.

\section{Profitabilitas dan Nilai Perusahaan}

Teori yang dikemukakan oleh Modigliani dan Miller (1958) menyatakan bahwa nilai perusahaan ditentukan oleh profitabilitas perusahaan. Profitabilitas yang dimaksud adalah kemampuan perusahaan dalam menghasilkan laba bersih sebelum bunga dan pajak. Hasil positif menunjukkan bahwa semakin tinggi profitabilitas semakin tinggi profit margin yang diperoleh perusahaan. Hal ini akan 
berdampak pada nilai perusahaan. Semakin besar tingkat profitabilitas maka semakin baik bagi perusahaan itu sendiri. Semakin tinggi tingkat profitabilitas suatu perusahaan maka semakin besar tingkat kemakmuran yang diberikan perusahaan kepada pemegang saham. Semakin besar tingkat kemakmuran yang diberikan oleh perusahaan akan menarik minat investor untuk memiliki perusahaan tersebut dan akan memberikan pengaruh positif terhadap harga saham di pasar. Ini berarti akan menaikkan nilai perusahaan.

\section{PEMBAHASAN}

1. Analisis

a. Analisis Deskriptif Kualitatif

1) Gambaran Profitabilitas pada Perusahaan Sektor Aneka Industri yang Tercatat di Bursa Efek Indonesia

Dari hasil penelitian, ada beberapa perusahaan di sektor aneka industri yang rasio return on equitynya sangat kecil bahkan mencapai angka 0,0009 atau dalam arti bahwa perusahaan tersebut hanya mampu menghasilkan profitabilitas atau laba sebesar 0,09\% dibandingkan total ekuitasnya. Dari hasil pengamatan, angka 0,0009 tersebut terdapat pada PT. Multistrada Arah Sarana Tbk. pada tahun 2012.Ini berarti pada tahun 2012 perusahaan tersebut hanya mampu menghasilkan laba bersih sebesar 0,09\% dibandingkan dengan ekuitasnya.

Di sisi lain, ada juga perusahaan di sektor ini yang angka return on equitynya sangat baik bahkan mencapai angka 0,4754 atau dalam arti bahwa perusahaan tersebut mampu menghasilkan profitabilitas atau laba bersih sebesar $47,54 \%$ dibandingkan total ekuitas yang dimilikinya. Dari hasil pengamatan, angka 0,4754 terdapat pada PT. Indospring, Tbk pada tahun 2012.

\section{2) Gambaran Nilai Perusahaan pada Perusahaan Sektor Aneka Industri yang Tercatat di Bursa Efek Indonesia}

Dari hasil peneliitan, ada beberapa perusahaan di Sektor Aneka Industri yang rasio market to book rationya sangat kecil bahkan mencapai angka 0,0098 atau dalam arti bahwa perusahaan tersebut hanya dihargai sebesar $0,98 \%$ dibandingkan nilai bukunya. Dari hasil pengamatan, angka 0,0098 tersebut terdapat pada PT. Sepatu Bata Tbk. pada tahun 2008. Ini berarti pada tahun 2008 harga saham perusahaan tersebut hanya dihargai sebesar 0,98\% dibandingkan dengan nilai bukunya.

Di sisi lain, ada juga perusahaan di sektor ini yang angka market to book rationya sangat baik bahkan mencapai angka 4,4314. Angka ini ada pada PT. Selamat Sempurna, Tbk. pada tahun 2012. Ini berarti pada tahun 2012 harga saham perusahaan PT Selamat Sempurna Tbk. dihargai sebesar 443,14\% dibandingkan dengan nilai bukunya.

\section{b. Analisis Deskriptif Kuantitatif}

1) Analisis Regresi Sederhana

Berdasarkan hasil analisa dengan program SPSS, maka model persamaan regresi adalah sebagai berikut: $\mathrm{MBR}=0,380+3,270 \mathrm{ROE}+\varepsilon$. Berdasarkan hasil persamaan regresi di atas maka dapat disimpulkan bahwa profitabilitas berpengaruh positif terhadap nilai perusahaan.

\section{2) Koefisien Korelasi dan Determinasi}

Berdasarkan hasil pengolahan data SPSS diperoleh nilai koefisien korelasi adalah sebesar 0,457 . Dengan demikian dapat dikatakan bahwa korelasi atau hubungan antara Profitabilitas terhadap Nilai Perusahaan pada Sektor Aneka Industri yang tercatat di Bursa Efek Indonesia adalah lemah. Untuk nilai koefisien determinasi adalah sebesar 0.209 yang berarti bahwa market to book ratio dapat dijelaskan return on equity sebesar 20,9\% pada Sektor Aneka Industri, sisanya sebesar $79,1 \%$ dijelaskan oleh variabel lain yang tidak dimasukkan dalam model penelitian ini misalnya return on assets, return on investment, net margin atau profit margin on sales dan basic earning power.

\section{3) Uji t} berikut:

Adapun hipotesis yang diuji adalah sebagai

a) Ho : $\beta=0$, artinya profitabilitas perusahaan tidak berpengaruh positif dan signifikan terhadap Nilai Perusahaan pada Sektor Aneka Industri yang tercatat di Bursa Efek Indonesia.

b) Ha : $\beta \neq 0$, artinya profitabilitas berpengaruh positif dan signifikan terhadap Nilai Perusahaan pada Sektor Aneka Industri yang tercatat di Bursa Efek Indonesia.

Dengan tingkat kepercayaan 95\% dan $\mathrm{n}=90$, dari tabel $\mathrm{t}$ diperoleh angka $\mathrm{t}_{\text {tabel }}$ sebesar 1,662, diperoleh besar $t_{\text {hitung }}$ untuk ROE adalah 4,825. Karena $t_{\text {hitung }}>t_{\text {tabel }}$ atau 4,825>1,662 maka Ho ditolak artinya Profitabilitas berpengaruh positif dan signifikan terhadap Nilai Perusahaan Sektor Aneka Industri yang tercatat di Bursa Efek Indonesia.

\section{Evaluasi}

a. Profitabilitas Perusahaan pada Sektor Aneka Industri yang Tercatat di Bursa Efek Indonesia.

Dari hasil penelitian, rata-rata return on equity pada Sektor Aneka Industri yang tercatat di Bursa Efek Indonesia berada pada 0,135610. Hal ini menunjukkan bahwa perusahaan yang tercatat pada Sektor Aneka Industri rata-rata hanya mampu menghasilkan laba bersih sebesar 13,56\% dibandingkan dengan ekuitasnya. Namun melihat angka $13,56 \%$ ini masih jauh di bawah rata-rata return on equity untuk perusahaan manufaktur yang tercatat di Bursa Efek Indonesia yaitu sebesar 20,67\% yang diteliti oleh Agustina (2013).

b. Perusahaan pada Sektor Aneka Industri yang Tercatat di Bursa Efek Indonesia 
Dari hasil penelitian, rata-rata market to book ratio pada Sektor Aneka Industri yang tercatat di Bursa Efek Indonesia berada pada 0,823262. Hal ini menunjukkan bahwa rata-rata harga pasar saham perusahaan yang tercatat pada Sektor Aneka Industri adalah sebesar 0,823262 kali dibandingkan dengan nilai bukunya. Namun angka 0,823262 ini masih jauh di bawah nilai perusahaan untuk perusahaan manufaktur yang tercatat di Bursa Efek Indonesia yaitu sebesar 2,2233 yang diteliti oleh Agustina (2013).

\section{KESIMPULAN DAN SARAN}

\section{Kesimpulan}

a. Rata-rata tingkat profitabilitas yang diproksikan oleh return on equity yang dihasilkan oleh perusahaan sektor aneka industri yang tercatat $\mathrm{di}$ Bursa Efek Indonesia adalah sebesar 13,56\%. Hal ini berarti rata-rata perusahaan di atas mampu menghasilkan laba bersih sebesar 13,56\% dibandingkan dengan ekuitas yang dimilikinya.

b. Rata-rata nilai perusahaan yang diproksikan oleh market to book ratio pada perusahaan sektor aneka industri yang tercatat di Bursa Efek Indonesia adalah sebesar 0,823262. Hal ini menunjukkan bahwa rata-rata harga pasar saham perusahaan yang tercatat pada sektor aneka industri adalah sebesar 0,823262 kali dibandingkan dengan nilai bukunya.

c. Dari hasil pengujian regresi linear diketahui bahwa profitabilitas memiliki pengaruh positif dan signifikan terhadap nilai perusahaan.

\section{Saran}

a. Bagi investor dan calon investor disarankan untuk terlebih dahulu menganalisis tingkat profitabilitas khususnya dengan memperhatikan return on equity perusahaan sebelum berinvestasi karena profitabilitas sangat berpengaruh dalam menentukan harga saham. Hal ini terlihat dari banyaknya saham-saham yang under valued yang setelah diamati ternyata tingkat profitabilitasnya juga adalah sangat rendah.

b. Bagi peneliti selanjutnya sebaiknya objek penelitian yang digunakan tidak hanya terbatas pada perusahaan sektor aneka industri saja tetapi seluruh perusahaan yang tercatat di Bursa Efek Indonesia supaya bisa mendapatkan kesimpulan yang lebih tepat.

c. Sebaiknya perlu juga dilakukan penelitian dengan menggunakan rasio profitabilitas selain daripada return on equity dan rasio keuangan lainnya.

\section{E. DAFTAR PUSTAKA}

Atmaja, Lukas Setia, 2008, Manajemen Keuangan, Edisi 2, Yogyakarta: Andi Offset.

Brigham, Eugene F. dan Houston, Joel F., 2010, Dasar-dasar Manajemen Keuangan, Edisi Kesebelas, Jilid Satu, Jakarta : Salemba Empat.

2012, Dasar-dasar Manajemen Keuangan, Edisi Kesebelas, Jilid Satu, Jakarta: Salemba Empat.

Horne, James C.Van dan Wachowicz, Jr. John M., 2012, Prinsip-Prinsip Manajemen Keuangan, Edisi Ketigabelas, Jilid Satu, Jakarta: Salemba Empat.

Modigliani, F. dan M. Miller. 1958. The Cost of Capital, Corporation Finance and The Theory of Investment, Journal American Economic Review, Volume XLVIII. 